\title{
PENGARUH KOMPETENSI SUMBER DAYA MANUSIA DAN SISTEM INFORMASI AKUNTANSI TERHADAP KUALITAS LAPORAN KEUANGAN
}

\author{
Animah') \\ Jurusan Akuntansi FEB Universitas Mataram \\ animahmtr@unram.ac.id \\ Adhitya Bayu Suryantara2) \\ Jurusan Akuntansi FEB Universitas Mataram \\ adhityabayus@unram.ac.id \\ Widia Astuti ${ }^{3}$ \\ Jurusan Akuntansi FEB Universitas Mataram \\ widia7@ymail.com
}

\begin{abstract}
A truly performance of a company can be shown when the financial statement published has high quality. This study aims to determine the effect of human resource competence and accounting information systems on the quality of financial reports. The data in the study were obtained through questionnaires distributed to accounting information system employees from the MSMEs in West Lombok. The novelty of this study is the use of a sample of MSMEs in West Lombok that have used information system in the management of financial transaction. The research data was obtained from 76 respondents, which then analyzed by performing multiple linear regression analysis. The results showed that the competence of human resources had no effect on the quality of financial reports, this was due to the low quality of human resources owned by MSMES related to the understanding of SAK ETAP, so that the resulting financial reports were of doubtful relevance and evidence. Meanwhile the accounting information system were found to have effect on the quality of financial reports.
\end{abstract}

\section{Keywords: accounting information system, financial report, human resource competence, quality}

\footnotetext{
Abstrak

Laporan keuangan suatu perusahaan dapat menunjukkan kinerja sesungguhnya jika laporan keuangannya berkualitas. Penelitian ini bertujuan untuk mengetahui Pengaruh kompetensi sumberdaya manusia dan system informasi akuntansi terhadap kualitas laporan keuangan. Data
} 
dalam penelitian ini diperoleh dari kuesioner dengan responden karyawan bagian system informasi akuntansi di UMKM. Kebaruan penelitian ini menggunakan sampel UMKM yang berada di wilayah Lombok Barat dan sudah menggunakan system informasi dalam pengelolaan transaksi keuangan. Jumlah responden sebanyak 76 orang. Alat analisis yang digunakan adalah regresi berganda dengan menggunakan SPSS. Hasil penelitian menunjukkan bahwa kompetensi sumberdaya manusia tidak berpengaruh terhadap kualitas laporan keuangan, hal ini disebabkan karena masih rendahnya pemahaman SAK ETAP sumberdaya manusia yang dimiliki oleh UMKM, sehingga laporan keuangan yang dihasilkan masih diragukan relevansi dan keandalannya. Sedangkan system informasi akuntansi berpengaruh terhadap kualitas laporan keuangan.

\section{Kata kunci: sistem informasi akuntansi, laporan keuangan, kualitas, kompetensi sdm}

\section{PENDAHULUAN}

Saat ini jumlah usaha kecil di Indonesia sudah mencapai 93,4 persen, dan usaha menengah berada di angka 5,1 persen, sedangkan usaha besar hanya 1 persen. UMKM (Usaha Mikro Kecil Menengah) di Indonesia sudah terbukti menjadi penggerak di tengah lesunya ekonomi. Pelaku UMKM telah menyumbang Produk Domestik Bruto (PDB) nasional hingga 60 persen dan menyerap 97 persen tenaga kerja (Latief, 2018). UMKM juga menunjukan peran yang cukup vital dari segi kuantitas dan penyerapan tenaga kerja. Meskipun terdapat beberapa manfaat positif, namun UMKM ini masih dipandang sebagai usaha yang lemah kinerjanya (Mufidah dan Fibriyani, 2017).

Barbara (2000) dalam Harahap (2014) menyatakan bahwa pengembangan kinerja UMKM ini sangat dipengaruhi oleh bidang pemasaran, keuangan dan teknologi. Kinerja keuangan suatu usaha dapat terlihat dari laporan keuangannya. Laporan keuangan suatu perusahaan dapat menunjukkan kinerja sesungguhnya suatu perusahaan jika laporan keuangannya berkualitas. Berkualitasnya suatu laporan keuangan apabila memiliki aspek dapat dipahami, relevan, keandalan, dan dapat dibandingkan (IAI, 2017).

Beberapa peneliti menyatakan bahwa kualitas laporan keuangan sangat ditentukan oleh kompetensi sumber daya manusia, karena dengan sumber daya manusia yang kompeten, maka akan dihasilkan laporan keuangan yang tepat waktu, relevan, dan dapat dibandingkan (Pujanira dan Taman, 2017), (Andini dan Yusrawati, 2015). Baihaqi (2016) menyatakan bahwa pemilik atau pengelola UMKM yang memiliki pengetahuan akuntansi akan menghasilkan laporan keuangan yang berkualitas. Selain itu untuk menghasilkan laporan keuangan yang 


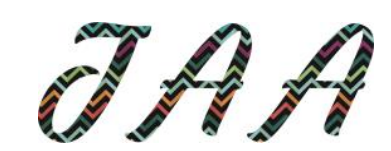

Vol. 5, No. 1, Oktober 2020

berkualitas tidak hanya ditentukan oleh kompetensi sumberdaya manusia tetapi juga sangat tergantung pada sistem informasi akuntansi yang digunakan di dalam suatu perusahaan (Andini dan Yusrawati, 2015). Sedangkan menurut Wijayanti (2017) diperoleh bahwa kompetensi sumber daya manusia tidak berpengaruh signifikan terhadap kualitas laporan keuangan.

UMKM yang ada di Lombok barat cukup bervariasi dari sektor industri, perdagangan maupun jasa dengan jumlah yang cukup signifikan yaitu sampai dengan tahun 2017 jumlah UMKM semua sektor 2599 dan yang terbanyak sektor perdagangan hampir $80 \%$. Selanjutnya UMKM yang bergerak di sektor perdagangan yang memiliki ijin usaha minimal usaha dagang hanya berkisar 180 usaha dan yang menggunakan sistem informasi akuntansi berbasis teknologi informasi hanya berjumlah 52 usaha. Hal ini terjadi karena beberapa alokasi usaha dagang yang tidak padat penduduk, kurangnya pengetahuan akan layanan kepada pelanggan oleh pemilik, belum adanya pemisahan harta pemilik dengan usaha, dan banyak pemilik beranggapan bahwa teknologi informasi tidak penting untuk meningkatkan usaha dagangnya. Oleh karena itu peneliti ingin meneliti apakah kompetensi sumberdaya manusia dan sistem informasi akuntansi mampu untuk menghasilkan laporan keuangan yang berkualitas sehingga memberikan dampak positif bagi pemilik di dalam pengambilan keputusan.

\section{TELAAH LITERATUR DAN PENGEMBANGAN HIPOTESIS}

\section{Kompetensi Sumberdaya Manusia}

Kompetensi merupakan kemampuan menjalankan tugas atau pekerjaan dengan dilandasi oleh pengetahuan, keterampilan, dan di dukung oleh sikap yang menjadi karakteristik individu (Wibowo, 2014). Mathis dan Jackson (2001) mengilustrasikan bahwa kompetensi ada yang terlihat dan ada yang tersembunyi. Pengetahuan lebih terlihat, dapat dikenali oleh perusahaan untuk mencocokkan orang dengan pekerjaan. Keterampilan walaupun sebagian dapat terlihat sebagian lagi kurang teridentifikasi, akan tetapi kompetensi tersembunyi berupa kecakapan yang mungkin lebih berharga dapat meningkatkan kinerja. Baihaqi (2016) menyatakan bahwa pemilik atau pengelola UMKM yang memiliki pengetahuan akuntansi akan menghasilkan laporan keuangan yang berkualitas. Kualitas laporan keuangan sangat ditentukan oleh kompetensi sumber daya manusia, karena dengan sumber daya manusia yang kompeten, maka akan dihasilkan laporan keuangan yang tepat waktu, relevan, dan dapat dibandingkan (Pujanira dan Taman, 2017), (Andini dan Yusrawati, 2015).

Standar diartikan sebagai ukuran atau patokan yang disepakati, sedangkan kompetensi diartikan sebagai kemampuan melaksanakan 
tugas-tugas ditempat kerja yang mencakup menerapkan keterampilan (skills) yang didukung dengan pengetahuan (cognitive) dan kemampuan (ability) sesuai dengan kondisi yang dipersyaratkan. Dengan demikian standar kompetensi dapat diasumsikan sebagai rumusan tentang kemampuan dan keahlian apa yang harus dimiliki oleh tenaga kerja (SDM) dalam melaksanakan pekerjaan sesuai dengan persyaratan yang ditetapkan/disepakati (LPPKMITB, 2005:3). Kompetensi erat kaitannya dengan kinerja, baik kinerja individu maupun kinerja organisasi (perusahaan). Menurut Armstrong (2004) kinerja seseorang didasarkan pada pemahaman ilmu pengetahuan, keterampilan, keahlian dan perilaku yang diperlukanuntukmelakukanpekerjaandenganbaik. Sedangkan kinerja organisasi (perusahaan) didasarkan pada bagaimana manajemen perusahaan merespon kondisi eksternal dan internalnya, yang dengan tolak ukur tertentu akan dapat diketahui berapa tingkat turbelensinya dan berapa tingkat kemampuan untuk mengantisipasinya.

\section{Sistem Informasi Akuntansi}

Sistem informasi akuntansi merupakan system informasi yang fungsional yang mendasari sistem fungsional lainnya seperti sistem informasi keuangan, system informasi pemasaran, sistem informasi produksi, dan sistem informasi sumber daya manusia. Sistem informasi lain membutuhkan data keuangan dari system informasi akuntansi. Pengertian sistem informasi akuntansi (SIA) menurut Bodnar dan Hopwood (2006), yaitu: Sistem informasi akuntansi merupakan kumpulan sumber daya, seperti manusia dan peralatan, yang dirancang untuk mengubah data keuangan dan data lainnya kedalam informasi. Informasi tersebut dikomunikasikan kepada para pembuat keputusan. Sistem informasi akuntansi melakukan hal tersebut entah dengan sistem manual atau melalui sistem terkomputerisasi. Laporan keuangan yang berkualitas tidak hanya ditentukan oleh kompetensi sumberdaya manusia tetapi juga sangat tergantung pada sistem informasi akuntansi yang digunakan di dalam suatu perusahaan (Andini dan Yusrawati, 2015).

\section{Kualitas Laporan Keuangan}

Kualitas laporan keuangan yang disajikan UMKM masih terbatas pada informasi penerimaan dan pengeluaran. Berdasarkan Kementrian Perdagangan (2013) lembaga pembiayaan juga berperan untuk memberikan bantuan teknis dalam hal pengelolaan keuangan dan sudah menjadi rahasia umum, bahwa UMKM memiliki kelemahan dalam pengelolaan keuangan. Padahal menurut pembukuan dan pelaporan keuangan merupakan hal yang penting dalam pertumbuhan dan perkembangan usahanya (Susanto dan Yuliani, 2015).

Seringkali tidak ada pemisahan antara rekening pribadi dengan rekening usaha, sehingga dana yang seharusnya digunakan untuk usaha 
akhirnya digunakan untuk mencukupi kebutuhan sehari-hari. Hal ini masih belum banyak menerapkan standar akuntansi yang diberlakukan untuk pengusaha UMKM yaitu SAK ETAP. Pengaruhnya banyak pengusaha UMKM yang kesulitan mendapat kredit perbankan atau jasa keuangan untuk memperluas usahanya. SAK ETAP menjadi harapan untuk dapat meningkatkan kualitas laporan keuangan UMKM menjadi lebih baik dari yang ada saat ini. Implementasinya di tahun 2011 nampaknya masih menemui kendala yang dikhawatirkan menghambat penerapan SAK ini. (Rudiantoro dan Siregar, 2012).

Karakteristik kualitas merupakan ukuran untuk menilai baik tidaknya sebuah laporan keuangan. IAI (2017) menyebutkan bahwa kualitas laporan keuangan harus memiliki aspek dapat dipahami, relevan, keandalan, dan dapat dibandingkan.

\section{Pengaruh Kompetensi Sumberdaya Manusia Terhadap Kualitas Laporan Keuangan}

Baihaqi (2016) menyatakan bahwa pemilik atau pengelola UMKM yang memiliki pengetahuan akuntansi akan menghasilkan laporan keuangan yang berkualitas. Kualitas laporan keuangan sangat ditentukan oleh kompetensi sumber daya manusia, karena dengan sumber daya manusia yang kompeten, maka akan dihasilkan laporan keuangan yang tepat waktu, relevan, dan dapat dibandingkan (Pujanira dan Taman, 2017), (Andini dan Yusrawati, 2015). Berdasarkan pernyataan di atas, maka rumusan hipotesisnya adalah:

\section{H1 = Kompetensi sumberdaya manusia berpengaruh terhadap kualitas laporan keuangan}

\section{Pengaruh Sistem Informasi Akuntansi Terhadap Kualitas Laporan Keuangan}

Sistem informasi akuntansi merupakan kumpulan sumber daya, seperti manusia dan peralatan, yang dirancang untuk mengubah data keuangan dan data lainnya kedalam informasi. Informasi tersebut dikomunikasikan kepada para pembuat keputusan. Sistem informasi akuntansi melakukan hal tersebut entah dengan sistem manual atau melalui sistem terkomputerisasi. Laporan keuangan yang berkualitas tidak hanya ditentukan oleh kompetensi sumberdaya manusia tetapi juga sangat tergantung pada sistem informasi akuntansi yang digunakan di dalam suatu perusahaan (Andini dan Yusrawati, 2015). Berdasarkan pernyataan di atas, maka rumusan hipotesisnya adalah:

\section{H2 = Sistem Informasi akuntansi berpengaruh terhadap kualitas laporan keuangan}




\section{METODE PENELITIAN}

Jenis penelitian ini adalah penelitian asosiatif dengan menggunakan data primer dimana informasi atau data yang diperoleh berdasarkan pandangan, persepsi, tanggapan, dan penilaian dari karyawan atau pemilik di UMKM sector perdagangan Kabupaten Lombok Baratdengan cara memberikan kuesioner. Populasi dalam penelitian ini adalah UMKM di Kabupaten Lombok Barat yang bergerak di sektor perdagangan sejumlah 180. Teknik pengambilan sampel dalam penelitian ini adalah purposive sampling dan jumlah sampel 76 UMKM dengan kriteria : (1) Perusahaan dagang yang memiliki izin usaha dalam bentuk UD, (2) UD yang menggunakan IT dalam kegiatan usahanya. Adapun variabel yang akan dianalisis dalam penelitian ini diklasifikasikan dan diukur seperti penjelasan berikut:

1. Kompetensi sumber daya manusia (X1)

Kompetensi diartikan sebagai kemampuan melaksanakan tugas-tugas ditempat kerja yang mencakup menerapkan keterampilan (skills) yang didukung dengan pengetahuan (cognitive) dan kemampuan (ability) sesuai dengan kondisi yang dipersyaratkan (Ardiana et al., 2010).

2. Sistem informasi akuntansi (X2)

Sistem informasi akuntansi merupakan kumpulan sumber daya, seperti manusia dan peralatan, yang dirancang untuk mengubah data keuangan dan data lainnya ke dalam informasi (Susanto, 2017). Informasi tersebut dikomunikasikan kepada para pembuat keputusan. Sistem informasi akuntansi melakukan hal tersebut entah dengan sistem manual atau melalui system terkomputerisasi (Bodnar dan Hopwood, 2006). Efektivitas system informasi akuntansi ini dilihat dari penerapan (Kristiani, 2012) serta pemanfaatan dan kemudahan (Jogiyanto, 2007).

3. Kualitas laporan keuangan (X3)

Laporan keuangan dibuat sebagai alat pertanggungjawaban manajemen terhadap pemilik perusahaan menyajikan laporan keuangan menurut PSAK No.1 (2017) yaitu 1) laporan posisi keuangan, 2) Laporan Laba Rugi Komprehensif, 3) Laporan Perubahan Ekuitas, 4) Laporan Arus Kas, 5) Catatan Atas Laporan Keuangan. IAI (2017) menyebutkan bahwa kualitas laporan keuangan berbasis ETAP meliputi aspek dapat dipahami, relevan, materialitas, keandalan, substansi pengumpulan bentuk, pertimbangan sehat, kelengkapan, dapat dibandingkan dan tepat waktu.

Sebelum dilakukan uji hipotesis terlebih dahulu diguakan uji validitas dan reliabilitas serta asumsi klasik. Pengujian hipotesis dengan menggunakan analisis regresi berganda dengan pengolahan menggunakan SPSS (Ghozali, 2016). Adapun model penelitian ini adalah sebagai berikut: 


\section{$J A A$}

Vol. 5, No. 1, Oktober 2020

$\mathrm{Y}=\mathrm{a}+\beta_{1} \mathrm{X}_{1}+\beta_{2} \mathrm{X}_{2}+\mathrm{e}$

Keterangan :

$Y=$ Variabel kualitas laporan keuangan

$\mathrm{a}=$ Konstanta

$\beta_{1} \ldots \beta_{5}=$ Koefisien regresi masing-masing variable independen

$\mathrm{sX}_{1}=$ Variabel dependen 1 Kompetensi sumberdaya manusia

$\mathrm{X}_{2}=$ Variabel dependen 2 Sistem informasi akuntansi

$\mathrm{e}=$ error term

\section{HASIL PENELITIAN DAN PEMBAHASAN}

Hasil uji validitas atas instrumen kuesioner penelitian baik untuk variable kompetensi sumberdaya, system informasi akuntansi dan kualitas laporan keuangan valid dan reliable. Model penelitian juga terbebas dari uji asumsi klasik baikitu normalitas, heteroskedastisitas, multikolonearitas dan autokorelasi. Sedangkan hasil penelitian ini dapat diuraikan di bawah ini.

\section{Pengaruh Kompetensi Sumberdaya Manusia Terhadap Kualitas Laporan Keuangan}

Hasil penelitian menunjukkan bahwa kompetensi sumberdaya manusia tidak berpengaruh terhadap kualitas laporan keuangan. Hal ini dibuktikan dengan nilai probabilitas signifikansi 0.540 (lebih besar dari 0.05) sehingga hal ini menunjukan bahwa variabel kualitas Sumberdaya manusia tidak berpengaruh terhadap kualitas laporan keuangan. Berdasarkan nilai $\mathrm{t}$ hitung dan $\mathrm{t}$ tabel, variabel kualitas sumberdaya manusia memiliki $t$ hitung lebih kecil dari $t$ tabel $(-0.616<2.00172)$ sehingga semakin memperkuat pendapat bahwa $X 1$ tidak berpengaruh terhadap Y (H1 ditolak). Hal ini sesuai dengan hasil penelitian Wijayanti (2017) yang menyatakan bahwa kompetensi sumber daya manusia tidak berpengaruh signifikan terhadap kualitas laporan keuangan. Jadi kompetensi sumberdaya manusia tidak mempengaruhi kualitas laporan keuangan. Hasil penelitian ini tidak sejalan dengan penelitian Pujanira dan Taman (2017), (Andini dan Yusrawati. (2015) yang menemukan pengaruh antara kualitas sumberdaya manusia terhadap kualitas Laporan Keuangan.

Kompetensi sumberdaya manusia tidak berpengaruh terhadap kualitas laporan keuangan. Hal ini sesuai dengan hasil penelitian Wijayanti (2017) yang menyatakan bahwa kompetensi sumber daya manusia tidak berpengaruh signifikan terhadap kualitas laporan keuangan. Jadi kompetensi sumberdaya manusia tidak mempengaruhi kualitas laporan keuangan. Berdasarkan data yang diperoleh dari responden rata-rata pendidikan SMA (Sekolah Menengah Atas) dan pengetahuan akuntansi 
terutama SAK ETAP masih minim, sehingga kualitas laporan keuangan diragukan. Selain itu banyak sekali bisnis kecil yang tidak beroperasi sesuai dengan prosedur pemerintah dan perencanaan dilakukan berdasarkan reaksi pelanggan dan kekuatan pasar bukan berdasarkan laba yang diperoleh (Muhindo et al., 2014). Oleh karena itu UMKM harus mulai membuat catatan tentang produk dan layanan supaya dapat terlihat kinerja perusahaan mereka.

\section{Pengaruh Sistem Informasi Akuntansi Terhadap Kualitas Laporan Keuangan}

Hasil penelitian ini sejalan dengan penelitian (Andini dan Yusrawati, 2015) yang menunjukkan bahwa system informasi akuntansi berpengaruh terhadap kualitas laporan keuangan. Hal ini dibuktikan dengan nilai probabilitas signifikansi 0.000 (lebih besar dari 0.05). sehingga hal ini menunjukkan bahwa variabel system informasi akuntansi berpengaruh terhadap kualitas laporan keuangan. Begitu juga dengan nilai t hitung dan t tabel, variabel SIA juga memiliki $t$ hitung yang lebih besar dari $t$ tabel $(14.756>2.00172)$. Hal ini semakin memperkuat pendapat bahwa X2 berpengaruh terhadap $\mathrm{Y}$ ( $\mathrm{H} 2$ diterima). Berdasarkan hasil dari survey penelitian yang kami lakukan menunjukkan bahwa rata-rata UMKM sudah menggunakan system informasi akuntansi berbasis computer, hal ini sangat menguntungkan bagi UMKM karena dapat memperoleh informasi keuangan tepat waktu, relevan dan dapat dibandingkan. Organisasi didorong untuk menggunakan teknologi informasi secara efektif untuk meningkatkan keunggulan kompetitif mereka di abad ke-21 yang bergejolak ini (Aulianida et al., 2019). Jika perusahaan tidak melakukan investasi dibidang IT khususnya pada pelaporannya, maka perusahaan tersebut akan kalah dalam persaingan. Serta dengan penggunaan SIA dapat memudahkan Usaha Kecil Menengah (UKM) dapat dengan mudah meminjam dana di Bank (Grande et al., 2011).

\section{SIMPULAN}

Penelitian ini bertujuan untuk menguji pengaruh kompetensi sumberdaya manusia dan system informasi akuntansi terhadap kualitas laporan keuangan. Penelitian ini menggunakan 76 sampel penelitian dengan metode purposive sampling. Hasil dari pengolahan data dalam penelitian ini menunjukkan bahwa:

1. Kompetensi sumberdaya manusia tidak berpengaruh signifikan terhadap kualitas laporan keuangan.

2. Sistem informasi akuntansi berpengaruh signifikan terhadap kualitas laporan keuangan. 


\section{$D A A$}

Vol. 5, No. 1, Oktober 2020

Keterbatasan dalam penelitian ini adalah keterbatasan jumlah UMKM di sektor perdagangan yang menggunakan system informasi dalam pengelolaan usaha. Sehingga mengurangi kualitas pelaporan keuangan yang dihasilkan. Saran untuk penelitian selanjutnya adalah dapat menambah variabel lain misalnya dukungan pemilik di dalam pemanfaatan sistem informasi akuntansi. Nilai kebaruan dalam penelitian ini adalah tidak ada pengaruh kompetensi sumberdaya manusia terhadap kualitas laporan keuangan karena system informasi akuntansi yang digunakan masih sederhana dan terbatas hanya untuk mencatat transaksi penerimaan dari penjualan saja dalam arti bahwa metode yang digunakan atas persediaan menggunakan metode fisik, sehingga pengambilan keputusan atas persediaan menjadi lambat oleh karena itu untuk meningkatkan kualitas system informasi diperlukan dukungan manajemen didalam pengadaan system yang smart teknologi dala arti sesuai dengan kebutuhan UMKM dan berbasis ETAP.

\section{DAFTAR PUSTAKA}

Andini,D., dan Yusrawati.(2015). Pengaruh Kompetensi Sumberdaya Manusia dan Penerapan Sistem Akuntansi Keuangan Daerah Terhadap Kualitas Laporan Keuangan Daera. Jurnal Ekonomi, Manajemen Dan Akuntansi, 24,(Juni 2015),65-82

Ardiana. I.D.K.R,Brahmayanti,I,A.,\& Subaedi.(2010).Kompetensi SDM UKM dan Pengaruhnya Terhadap Kinerja UKM di Surabaya.Jurnal Manajemen dan Wirausaha,12(1),42-55. https://doi/10.9744/jmk.12.1.pp.42-55

Armstrong, M. (2004). Performance Management. Tugu Publisher. Nyutran (terjemahan).

Aulianida,D.,Liestyasari,S.I\&Ch,S.R.(2019)Journal of Chemical Information and Modeling,53(9), 1689-1699

Baihaqi, M. (2016). Pengantar Psikologi Kognitif. PT Refika Aditama

Bodnar, GH \& Hopwood, W.(2006). Accounting Information System. Prentice Hall, New Jersey

Ghozali,I.(2016).Aplikasi Analisis Multivariate dengan Program IBM SPSS (Edisi Kelima). Badan Penerbit Universitas Diponegoro.

Grande, Elena Urquía; Estebanez,R.P.,Colomina, C. M.(201). The Impact Of Accounting Information Systems (AIS) On Performance Measures: Empirical Evidence In Spanish SMEs.International Journal of Digital Accounting Research. 11(January), 2543.Https://doi.org/10.4192/1577-8517-v11_2 
Harahap, Y.R.(2014). Kemampuan Menyusun Laporan Keuangan Yang Dimiliki Pelaku UKM Dan Pengaruhnya Terhadap Kinerja UKM. Riset Akuntansi Dan Bisnis, 14(2002),52-65

Indonesia, I.A. (2017). Pernyataan Standar Akuntansi Keuangan, Penerbit Salemba Empat

Jogiyanto. H. (2007). Sistem informasi keperilakuan. CV. Andi

Kristiani. W. (2012). Analisis pengaruh efektivitas teknologi sistem informasi akuntansi terhadap kinerja individual pegawai PT. Kim Eng Sekuritas Indonesia. Jurnal Fakultas Ekonomi Universitas Gunadarma.

Latief.(2018).Masih Banyak Pelaku UMKM"Buta"Akuntansi.Kompas.Com

Mathis.L.R. dan Jackson.H. 2001, Manajemen Sumber Daya Manusia (Buku kedua). Jakarta

Mufidah, E dan Fibriyani, V. (2017). Peran Wirausaha dan Kompetensi Sumber Daya Manusia Terhadap Kinerja UKM Industri Makanan. AKADEMIKA, 15(2)

Muhindo,A.,Zhou,J.,\& Kapute Myuzuza,M (2014)Impact of Logistics Outsourching Strategy in Oil and Gas Industry in Urganda. International Journal of Business and Management, 9(6) https://doi.org/10.5539/ijbm.v9n6p187

Pujanira, P.,\& Taman, A.(2017). Pengaruh Kompetensi Sumber Daya Manusia, Penerapan Standar Akuntansi Pemerintahan dan Penerapan Sistem Akuntansi Keuangan Daerah terhadap Kualitas Laporan Keuangan Pemerintah Daerah Proviinsi DIY.Nominal, Barometer Riset Akuntansi Dan Manajemen,6(2).https://doi.org/10.21831/nominal.v612.16643

Rudiantoro, R., \& Siregar, S. V.(2012). Kualitas Laporan Keuangan UMKM Serta Prospek Implementasi SAK ETAP. Jurnal Akuntansi Dan Keuangan Indonesia 9 (1), 1-21. https://doi.org/10.21002/jaki.2012.01

Susanto, A.(2017).Sistem Informasi Akuntansi Pemahaman Konsep Secara Terpadu.Lingga Jaya

Susanto, B., \& Yuliani, N. L. (2015). Prospek Implementasi SAK ETAP Berbasis Kualitas Laporan Keuangan UMKM. Optimum: Jurnal Ekonomi Dan Pembangunan, 5(1),1. https://doi.org/10.12928/optimum.v5i1.7796

Wibowo. (2014). Manajemen Kinerja. Rajawali Pers 
Wijayanti,L (2017). Pengaruh Kompetensi Sumberdaya Manusia, Sisitem Pengendalian Intern, Dan Teknologi Informasi Terhadap Kualitas laporan Keuangan Pemerintah Daerah (Studi Empiris Pada Dinas Pendapatan Pengelolaan Keuangan Dan Aset Daerah (DPPKAD) Kabupaten Sukoharjo).Artikel IImiah Akuntansi.1-9. 